\title{
THE DEVELOPMENT OF ENGLISH LEARNING MODEL BASED ON CONTEXTUAL TEACHING AND LEARNING (CTL) IN JUNIOR HIGH SCHOOLS
}

\author{
Munir Munir \\ Universitas Negeri Makassar, Indonesia \\ Email:munir@unm.ac.id \\ Riola Haya Nur \\ Universitas Negeri Makassar, Indonesia \\ Email: riola@unm.ac.id \\ DOI : 10.26858/ijole.v2i1.4326
}

\begin{abstract}
Specific targets of this research are: (1) Lesson Plan (RPP) for junior high school students, (2) Student Worksheet; and CTL-based student books. The long-term goal to be achieved is the occurrence of a CTLbased English language learning process that can improve the English language skills of junior high school students in South Sulawesi. The method used to achieve the purpose of this research is Research and Development (R \& D) by studying a number of models of learning device development, to further select and apply the device development model by the characteristics of subjects and background of psychology development of junior high school students. Repeated trials of instructional devices were conducted to obtain the best prototype learning tools that meet the needs of junior high school students in South Sulawesi. The results of data analysis show that (1) one way to improve students' communication skill and their critical thinking ability is by developing learning tools based on CTL English; (2) the factors that affect the inability to communicate in English is not the occurrence of English learning process that provides opportunities for students to use English maximal in the classroom. This is in contrast to the learning process undertaken with CTL-based learning where students have the opportunity to speak and think critically to discuss the real problems faced in front of their classmates to maintain the results of the projects they report. In addition, with the learning tools based on CTL, it was also found that the ability to interact in English students with classmates as well as to teachers also seemed to increase.
\end{abstract}

Keywords: CTL Based learning, critical thinking

\section{INTRODUCTION}

In connection with the implementation of the National Standards of Education in Indonesia, there are many things that schools need to prepare in each region. The School shall prepare the 2013 Curriculum consisting of educational unit level objectives, structure and content, educational calendar, and syllabus by means of the translation and adjustment of the Content Stand established by Educational Ministry Decree no. 22 year 2006 and the Graduate Competency Standards established with Educational Ministry Decree no. 23 year 2006. The school / madrasah and school committees should develop their education unit curriculum and syllabus based on the basic framework of the curriculum and the standard of graduation competency.

Behind all that the researchers realize that along with the implementation of 2013 curriculum, teachers are required to make changes in accordance with the learning approaches that are in line with the curriculum. However, the reality on the ground is not what it expected to be. Teachers generally complain about the reasons behind their lack of understanding of the 2013 curriculum concepts. In addition, there are still many 
teachers who use materials and learning aids that are not contextual in accordance with the needs of students. Teachers in South Sulawesi generally still use books published outside of South Sulawesi, whose content is not very supportive of learning that can improve the ability to think critically in the context of the problems of South Sulawesi. Therefore, the most urgent problem to be addressed in this development study is to develop a learning model that has been used by most teachers to be considered ineffective in improving language competence and critical thinking of students especially in junior high school according to the context of the problems in South Sulawesi.

Based on the background and road map of research that has been stated above, then the formulation of the problem in this study are:

(1) How to develop English learning program plan (RPP) and student worksheet (LKS) based on CTL in order to improve students' communication skill in English and critical thinking ability?

(2) What factors affect the implementation of the learning program plan (RPP), the student workbook in English and the CTLbased student book taught to junior high school students in South Sulawesi?

The three formulations of the above problems are answered using descriptive statistics and qualitative data analysis.

\section{LITERATURE REVIEW}

The enactment of Law of the Republic of Indonesia number 22 of 1999 on regional government and government regulation number 25 year 2000 regarding authority of government and authority of provinces as autonomous region bring implication to the implementation of autonomy and democratization in education implementation.

As a follow-up of the enactment of the Act, the government has made curriculum changes which later became known as the 2013 curriculum which is a refinement of the KTSP
Curriculum - is an operational curriculum developed and implemented by each educational unit / school. The National Department of Education expects no later than the year 2015, every school has implemented 2013 curriculum. In 2013 curriculum, schools are provided with flexibility in designing, developing and implementing school curricula in accordance with the situations, conditions and potential local benefits that schools can generate. In addition, the school can also develop higher standards of content standards and graduate competency standards with reference to the basic and secondary 2013 curriculum guidelines made by BNSP (Rustama, 2002).

This curriculum is certainly not simple, therefore various parties must be involved in order to enforce it. One of the efforts to be done is to provide learning tools such as lesson plans, LKS, student books, and evaluation instruments. However, in this research will be focused on the development of CTL-based learning instrument or learning tool.

As it is known that today's learning paradigm has changed from the old pattern, namely teacher-oriented learning, teachercentered instruction, toward learning that focuses on the learners, learner-centered instruction. This paradigm shift in direction or learning tendencies ultimately changes the interaction patterns of learning in the classroom. The first pattern of learning places the learner as the only source of learning, in contrast to the second pattern of placing learners as the focus of learning. This change has been inspired by the existence of new theories and approaches in today's learning practice. One application or applied learning, based on this theory is CTL-based learning. Learning based on CTL is a method or way of learning, or perhaps in training, characterized by real experience, a real-world experience, as a context for learners to learn critical thinking and problem-solving skills and gain 
knowledge. This subject includes both knowledge and action.

This CTL based learning problem can be used in individual and group learning process. This method can also be applied in the sphere of classroom setting and other types of learning. Even this CTL-based learning can be applied to employees or professionals to prepare them for new tasks or promotional interests. This is often done with case-based learning. At the present time, CTL applications are also done using online or network learning tools, both intranet and internet.

\section{Why CTL Based Learning?}

If we as a teacher or teacher (learner) or coach, or even as a manager of a company, we have two goals when we prepare someone with a new task. The first goal, is to maximize the endurance of retention or retention. We do not want the things we learn to walk in or out of power at all. We do not have any special time to train a person, so we need to make sure that the durability of the reminders is high. Our second goal, is to ensure the delivery of information that is not just a transfer of knowledge. For that, we need to make learners able to apply their knowledge and skills in every situation. The best thing we do is to provide a platform that allows learners to build things to respond to new situations or different situations.

As we have seen, so far the learning or training formats are more monopolized by content. Learning or training is done with a presentation strategy that is mosnotonous and does not provide opportunities for learners to articulate about what is learned, tends to be boring (Nur, 2000). For this reason, a better learning approach is done through problemsolving, decision-making, and self-directed learning. These things can be done by applying CTL, which provides the foundation for a more lively learning because applying a learner's CTL applies knowledge and skills, not just accepting it (Nurhadi, 2002; Ommundsen, 2001).

\section{The Benefit of CTL}

The most prominent advantage of CTL is that it provides an opportunity for learners to solve problems according to individual ways or learning styles (visual, auditive, kinesthetic) and by type of intelligence (plural intelligence, according to Gardner, (2006). Multiple intelligences, multiple intelligences (MIs), as defined, by Gardner, are a variety of ways of developing intellectual ability. By knowing each individual learning style (learners), we are expected to help adjust to the approach we use in learning.

Another advantage associated with the application of CTL is the development of critical thinking skills (critical thinking skills). Learners are trained to develop ways of finding (discovery), questioning, articulating, explaining or describing considering or making considerations, and making decisions. Thus, learners apply a process of work through a real situation, a situation that contains student experience. The processes passed by these learners are familiar with the CTL stages.

\section{Stages of CTL}

As we explain in advance that this CTL requires learners to deal with what they already know and what they do not know yet (Silberman, 1996). This situation invites them to ask questions, do research, and determine what action will be taken. The following steps are one troubleshooting model. In the first stage, to the learner presented the problems or questions unstructured (ill-structure problem). According to Lepinski (2005) the following stages of problem-solving are: 1) conveying ideas, 2) known facts presentation, 3) learning issues, 4) formulating action plans, and 5) evaluation.

\section{Stage 1: Conveying Ideas}


At this stage, brainstorming takes place. Students record all the list of problems (ideas) to be solved. They are then invited to review the ideas presented or examine the importance of the relevance of the ideas with regard to the problem to be solved (actual problems, or issues relevant to the curriculum), and to determine the validity of the problem for working through the problem.

\section{Stage 2: Known Facts Presentation}

At this stage, the learners are invited to list a number of supporting facts in accordance with the proposed problem. This stage helps clarify the difficulties raised in the problem. This stage may also include the knowledge that the learners already have with regard to specific issues, such as violations of ethical codes, conflict resolution techniques, and so on.

\section{Stage 3: Learning Issues}

The learners are asked to answer the question, "What do we need to know to solve the problems we face?" After conducting discussions and consultations, they conduct research and gather information. Learners look back at the initial ideas to determine which ones can still be used. Often, when learners present problems, they find new ways to solve problems. Thus, it can be a process or action to eliminate unbreakable ideas or otherwise ideas that can be used to solve problems.

\section{Stage 4: Formulating Action Plans}

At this stage, learners are invited to develop an action plan based on their findings. This action plan is something they will do or in the form of a recommendation suggestions to solve the problem.

\section{Stage 5: Evaluation}

This evaluation stage consists of three things: 1) how learners and evaluators evaluate the product (outcome) of the process, 2) how they apply the CTL stages to work through problems, and 3) how learners will convey the knowledge of the CTL outcome or as a form their accountability.

Learners deliver the results of their assessment or responses in various forms, eg: verbally or verbally, written reports, or as some other form of formal presentation. Evaluator assess the mastery of study materials at that stage through the learners. Part of the evaluation focuses on problem solving by learners and by collaborative learning (working with others). A tool for assessing results can be used in a Rubric. Rubric is used as a measurement tool to assess by several categories, for example: 1) time limit, 2) task organization (project), 3) language facet, 4) analytical skills, study, 5) ability to find source of support, including literature review), 6) creativity (description and reasoning), and 7) presentation form of presentation (Sudibyo, 2002)

\section{RESEARCH METHOD}

This research is Research Development (Development and Development) which aims to develop learning device in the form of lesson plan and student worksheet for junior high school student in South Sulawesi. Based on the observation of the teaching of English in junior high school so far, the model of development of learning tools that is closer and in accordance with the characteristic of students in South Sulawesi is a model of Thiagarajan (1974) (Four-D model).

Four-D device development model consists of four stages, namely define, design, development, and disseminate. The learning device development procedure in this research can be seen in the following steps:

1. Define Stage

This stage aims to define and define the terms of learning. Activities in this stage are front-end analysis, student analysis, material analysis, task analysis, and objectives specification of learning.

2. Design Stage 
The design stage is intended to design learning tools. Activities undertaken at this stage are the preparation of learning outcomes, media selection, format selection, and early design of learning tools.

3. Development Stage

The development stage is intended to produce prototypes of revised learning devices based on the results of prototype1 analysis. The input of experts and practitioners as well as the results of the analysis of learning activities is an important underlying development of the prototype in question. Activities at this stage are the assessment of experts and practitioners as well as field trials.

4. Disseminate Stage

Disseminate stage is carried out by conducting activities of dissemination of learning devices through limited seminar activities involving teachers, students, teachers, and the public.

\section{Participants}

The subject of this research was 99 junior high school students in South Sulawesi and they were taken purposively.

\section{Instrument and Data Collection}

1. The Learning Device's Validation Sheet Validation of learning tools is done qualitatively with English experts. Validator (Brendon Marshal from Australia) is asked to provide a qualitative assessment by filling free comments, in order to avoid the subjectivity of the validator.

2. Checklist Observation

a. Students' Activity Observation Sheet Student activities observed at this stage include attention to teacher and other students' explanations, discussion with friends, reading (lesson plan, student worksheet), discussions with teachers, other irrelevant behaviors.

b. The Teacher's Observation Sheet Manages the Learning

The teacher's ability to manage the learning materials is structured to obtain data about the teacher's ability to manage learning as one of the supporting data on the effectiveness of CTL-based learning in relation to the ability of the device to improve communication competence and critical thinking ability.

\section{c. Observation sheet of learning}

The way to collect field data about the practicality of the learning device is by providing observation sheets to the observer for use in observing the implementation of aspects or components of the learning device when the teacher carries out the classroom instruction as directed.

3. Student's Response Questionnaire

Student response data on field test activities is obtained through qualitative responses. The students' responses revealed are responses to aspects of learning that include learning materials, Student worksheets, classroom learning atmosphere, the way teachers teach and the appearance of teachers.

\section{Learning Outcomes Test}

The level of competence to communicate students in accordance with learning materials that have become the topic of conversation by teachers and the ability of the device in improving the ability to think critically as a major indicator to measure the effectiveness of learning tools and as a 
consideration to improve the device that has been prepared.

\section{Technique of Data Analysis}

Development of learning tools using Descriptive Statistics analysis supported by qualitative analysis.

\section{Analysis of Learning Device Learning Data}

Activities undertaken in the process of data analysis implementation of learning devices are as follows:

(1) recapitulate the observation result of learning device implementation,(2) finding the average of each observation aspect of each meeting, (3) finding the average of each observation aspect for each meeting, (4) finding the total mean, and (5) determining the category the implementation of each aspect or the whole aspect by matching the average of each aspect or the total average with the predefined category (Paidi, 2000).

\section{Analysis of Students Response Data}

Student response data to instructional device include student response to student worksheet implementation of learning. Student responses to the learning implementation include responses to the learning atmosphere, the way the teacher teaches and the appearance of the teacher.

\section{Analysis of Test Data of Students Learning Result}

The collected data is analyzed quantitatively and qualitatively. Quantitative data analysis used Descriptive Statistics to describe Student mastery level.

\section{FINDINGS AND DISCUSSION}

Learning tool in this research is developed and developed based on four-D model from Thiagarajan (1974) consisting of four stages namely define, design, develop and
Disseminate. Activities undertaken at each stage are as follows:

Based on the study of learning activities in English language learning for junior high school students, the fundamental problem that needs to be solved is the tendency of learning so far that lacks sufficient opportunities for students to develop their communication skills. As a result, students' social communication skills become passive, lazy to ask, let alone express their thoughts or opinions both in Bahasa Indonesia and English.

\section{Results of Student Analysis}

Communication characteristics of junior high school students who follow CTL-based English learning are classified as active in group, and less actively individual. Initial ability of students, to communicate in order to build cognitive development ability, tend to be better if the group and less good if individually. Thus the communication competence of students tends to be good but their ability to think critically by building and developing ideas, is quite good only for problems that use low-level language.

\section{Learning Materials Analysis Result}

The topic of English material is structured hierarchically based on the characteristics of the problems faced by the special community in South Sulawesi by referring to the national competency standard in relation to the students' communication skills.

\section{Results of Tasks Subject Analysis}

The results of the skills identification of the tasks performed by the students during and after implementing CTL-based learning are good, especially in terms of completing the tasks in the student worksheet. Analysis of student tasks includes understanding of the subject matter and learning objectives. In addition, the task becomes an indicator for them whether students have enough commitment and high appreciation to the 
material given, which is one of the foundation to build a conducive communication competencies and smoothly.

\section{Descriptive Statistics Analysis Result}

Descriptive Statistics analysis of learning tools that have been created and tested is.

Table 1. Results of Descriptive Analysis of Learning English Scores of Junior High School Students in South Sulawesi

\begin{tabular}{lllllll}
\hline Number of Respondents & $\begin{array}{l}\text { Ideal } \\
\text { Score }\end{array}$ & Average & $\begin{array}{l}\text { Standard } \\
\text { Deviation }\end{array}$ & Variance & $\begin{array}{l}\text { Minimum } \\
\text { Score }\end{array}$ & $\begin{array}{l}\text { Maximum } \\
\text { Score }\end{array}$ \\
\hline 99 & 100 & 77,99 & 20,12 & 404,81 & 0 & 96 \\
\hline
\end{tabular}

The table above shows that the result of study of junior high school student in English subject with research subject is 99 students got average score 77,99 from ideal score 100 and Standard Deviation 20,12. A minimum score of 0 and a maximum score of 96 .

Descriptive analysis showed that from 99 students who were the respondents of the research, there were 5 people $(5.05 \%)$ including very low category, 2 people $(2.02 \%)$ included low category, 4 people $(4.04 \%)$ included medium category, 19 (19.19\%) including High category and more than half or $69(69,70 \%)$ including very high category.

Based on the criteria set out in the previous chapter that a student is said to have good communicative competence if the score is in the category of at least high or is on score 65 . Classroom learning is said to be complete if at least $85 \%$ of students are at least high category or score 65 . Table 1 shows that there are 11 students who still score less than 65. This means that 11 students are individually incomplete in learning. While Students who complete learning through bilingual program is a student who scored 65-100, in this case there are 88 students from 99 students or $88.89 \%$ with the score of learning outcomes in high or very high category. Thus, the use of English language learning tools with an effective CTLbased approach to deliver students to understand the contents of Contextual English for junior high school students, as well as expected that this achievement has a positive relationship in improving the ability of critical thinking.

\section{Description of Results from Disseminate Stage}

The pre-packaged / prototype-3 learning tool is socialized to English teachers in junior high schools in Makassar City, Various responses and opinions from teachers and students are used in the improvement of next learning tools.

\section{Qualitative Descriptions of Research Results According to the Effectiveness of Learning Devices in Developing English student discussion skills}

In general, junior high school students who become respondents research, states that learning tools consisting of Student Book, lesson plan and student worksheet can improve communication competence and critical thinking skills of junior high school students. Besides the contents of the device that leads students to the above, it is also supported by the conditions and opportunities that enable them to interact better, among fellow students. However, the content of instructional devices on certain themes sometimes still makes it difficult for them to communicate fluently because of the vocabulary of vocabulary and the limited schema of the theme

Self-study ability is also increased with the existence of learning tools based on CTL based on the recognition of most of the research respondents. In addition to sociocultural support and psychological scenes, the CTL- 
based learning tool of English as its original characteristic is systematic, consistent and rational able to sharpen communicative competence among junior high school students. The effectiveness and efficiency of the English learning tool packaged more pronounced when the research respondents were able to use it as one of the foundations for learning English language lessons in junior high.

CTL-based learning tools written in English are also taught to improve social competence in relation to globalization in education.

\section{CONCLUSIONS AND SUGGESTIONS Conclusions}

Based on the results of the research and discussion that have been described in the previous chapter, the conclusion of this study is:

1. One way to improve the competence of English communication among students as well as to help improve the critical thinking ability of junior high school students is to develop a CTL-based learning tool consisting of Student Book, Lesson Plan and Student Worksheet written in English and taught by CTL-based approach.

2. Factors influencing the implementation of CTL-based English learning are the first language (mother tongue), social interaction with regional or ethnic viscosity value, and the basic ability of English students who become early provision in understanding learning tool.

\section{Suggestions}

1. It is suggested to the teacher that in order to improve the competence of English communication and students' critical thinking skills, the implementation of CTL-based approach in learning English in junior high schools in the development of learning tools becomes important to be implemented in the classroom. (2) Factors such as mother tongue, social interaction, ethnic viscosity value, and basic English proficiency of the students should be minimized as much as possible in order to build better communicative English competence.

\section{REFERENCES}

Gardner, Howard (2006) Changing Minds. The art and science of changing our own and other people's minds. Boston MA.: Harvard Business School Press.

Lepinski. (2005). Problem-Based Learning: A New Approach To Teaching, Training \& Developing Employees. Cokie Lepinski, Assistant Communications Manager of Marin County Sheriff's Office. [On line].Available:http://www.sacpd.org/R CPI/ [December 12, 2017]

Nur, M., 2000. Buku Panduan Keterampilan Proses dan Hakekat Sains. Surabaya:

Pusat Keterampilan teknik dan Matematika Program Pascasarjana.

Nurhadi, 2002. Peningkatan Kontekstual (Contextual Teaching and Learning $(C T L))$. Jakarta: Depdiknas Direktorat Jenderal Pendidikan Dasar dan Menengah Direktorat Pendidikan Lanjutan Pertama.

Ommundsen, P. 2001. Problem-Based Learning in Biology With 20 Case Examples. (Online), (http://vvww.saltspring.com'capewest/p bl.htm. Accessed 11 August 2006).

Paidi, 2000. Implementasi Authentic Assessment Dalam Pembelajaran IPA di Sekolah Dasar: JICA Proceeding Seminar Nasional Pengembangan Pendidikan MIPA di Era Globalisasi, Yogyakarta: Universitas Negeri Yogyakarta, 248-253.

Rustama, Cecep E., 2002. Manajemen Peningkatan Mutu Berbasis Sekolah. Buku 5, Jakarta: Depdiknas Direktorat Jenderal Pendidikan Dasar dan Menengah Direktorat Pendidikan Lanjutan Pertama. 
Silberman, M.,1996. Active Learning (Translation), Jakarta: Yappendis

Sudibyo, Elok., 2002. Analisis Tugas (Task Analysis). Presented in UNESA Surabaya dengan Dirjen Dikti Jakarta, Surabaya
Thiagarajan, S. Semmel, DS \& Semmel, MI. (1974). Instructional Development for Training Teachers of Exceptional Children. Indiana: Indiana University Bloomington 